\title{
MUSIC LISTENING AS MUSICKING AND STRONG MUSICAL EXPERIENCE
}

\author{
Mirdza Paipare \\ Liepaja University, Latvia
}

\begin{abstract}
Research about musical experience can be found in various works written about the experience of joy felt from music listening or seeing visual art. Gabrielsson and Lindström gathered and analysed more than 1000 case descriptions over a period of ten years, in which participants were asked to describe in as much detail as possible the most powerful and most impressive musical experiences they had ever had. References to such musical experiences in literature are not rare, however they are related to a variety of results - involving demographics, geography, environment, etc.

The author conducted a phenomenological analysis as a subjective psychological aspect's research method of musical experience, where music listening and musical experience 'goes together' with musicking.
\end{abstract}

Keywords: music listening, musicking ${ }^{l}$, strong musical experience, phenomenological research.

\section{Introduction}

There is an increasing number of publications dedicated to the use of music and its significance in human life. The author's interest in musical influence on humans draws on the fields of pedagogy, psychology and therapy.

Music listening, as a democratic form of musical perception, is available to everybody. It has been explored from a variety of viewpoints: as an everyday activity (DeNora, 2000; Ruud, 2004, Herbert, 2011), as an experience (Juslin \& Sloboda, 2001 Clarke, Dibben, \& Pitts, 2010), as a particular form of musicmaking (Small, 1998; Elliott, 1995), as a cognitive process (Paipare, 2006), as the inter-relation between the skills of listening and music listening in teacher education (Paipare, 2003), as an integrative operation of music perception (Paipare, 2004) and as empathic listening (Griten, 2015; Peters, 2015).

When conducting a phenomenological inquiry, it is insufficient simply to recall or collect another's experiences of a specific phenomenon. It is important that the essential aspects of this experience and the structures of meaning in our interpretation take first place, and that in the description we perceive it as a

\footnotetext{
${ }^{1}$ term created and used by Small, 1998.
} 
potential experience or, in other words, as a possible interpretation of this experience. Therefore the objective of phenomenological research and description becomes clear - to construct a possible interpretation of a specific human experience. This means that the first question the researcher has to ask oneself at the very beginning of the inquiry becomes, "Which human experience am I called to research?" Phenomenological research does not allow us to propose a research question and then distance ourselves from it. As van Manen indicates (van Manen, 1990), one has to live with this question and become this question.

Research participants were interviewed or wrote essays about autobiographical memories related to music or situations involving music, preferably in the first 10 years of life. As a result, memory records were acquired from professional musicians, music teachers and also people not professionally related to music. Participants were asked to answer the following questions:

1. At what age do you remember this event taking place?

2. Where did it happen?

3. With what kind of event was this $1^{\text {st }}$ musical experience associated? (Were you listening or performing yourself?)

4. Who were you with during this musical experience? (Describe the situation, environment.)

5. Can you say what kind of music it was and give a brief description?

6. Can you say if you have heard/listened to this music often?

7. What kind of role or meaning did this experience have for you at the time?

8. Was this experience significant in your subsequent musical behaviour or attitude towards music?

9. How often do you recall (if you do) this musical impression/ experience?

10. Other comments.

The goal of the analysis was to identify sentences or segments of meaning that revealed something especially significant in the context of the inquiry. Therefore, material collated from the Autobiographic memory study interviews and essays was tabulated and subjected to analysis in order to identify narrative fragments revealing the essence of the empirical musical experience. This also provided an opportunity to summarize the experiences of different people whilst looking for individual criteria of musical experience. Data processing started with organisation: sections of narrative that were not significant or relevant to the objective of the inquiry were discarded. The questionnaire of each respondent was reread multiple times to develop a feel for the contents, to select 
segments of meaning, arrange, categorize and lastly, develop an overview of the subject matter of the inquiry.

The aim of research was to identify strong musical experience in music listening and musicking process in autobiographic memory context.

\section{Participants and Methods}

240 full and part time students of various study programmes at Liepaja University (at that time LPA - Liepaja Pedagogical Academy) and 4 residents of Rigas Stradina University (RSU), aged 18-59, participated in the research. The methods used were interviews and phenomenological analysis of documents. Data from these documents was analysed in accordance with the four criteria of textual analysis formulated by Ricoeurin (1971), summarised by Von Eckartsberg:

1) fixation of meaning;

2) dissociation of the mental intention of the author from the text;

3) display of nonostensive references;

4) universal range of address (Von Eckartsberg, 1998: 50).

Theory played an insignificant role in the initial process of analysis, with attention paid only to the basic research theme - music listening experience.

At the next stage of data analysis the most expressive items were selected from each interview/essay group (taking into account the whole interview/essay series' correspondence to recurring themes). Giorgi's (1975, 1985) phenomenological method of analysis was used for this deeper exploration.

The goal for defining content units was to develop as precise as possible a focus on specific and concrete, versus general and vague statements; it was necessary to concentrate on content that had clear relevance to the object of the enquiry.

At the next stage categories were identified from a close study of content units. This involved grouping units which revealed a particular and significant nuance of the object of the research. Data analysis was carried out by a further two experts, reaching consensus on content units suitable for analysis and classification of those units in categories.

In the following stage the related categories were grouped in multiple segments, to bring out the meanings expressed in each and to elucidate dimensions that characterised the intra-psychological aspect of music listening in other words, the facet of music-making which is fundamental to the individual and can therefore be considered as music listening criteria.

Four dimensions were identified in the process of grouping categories according to themes expressed in the units of content:

1. the process of music listening and personal feelings related to it; 
2. the motivation for music listening, the meaning given to it by the person;

3. the spectrum of manifestations of music listening experience;

4. external reference of music listening, evaluation of product.

The dimension that includes the spectrum of manifestations of music listening experience contains only one category, but has sufficiently deep content to make it valuable.

\section{Conclusion}

As a result of this research the role of music-making and/or music listening in musical experience in solving personality development problems was formalised. Every person that participated in the research had the opportunity to pay attention to their "musical biography" as the main working tool and obtain information about their experience and its significance. The results of this research allow us not only to draw substantial conclusions about the role of musical experience in a person's life but also to ascertain its influence on important domains of human life that affect the senses, emotions, perception, behaviour, culture and identity. This kind of phenomenological research makes personal and social values visible, along with their related worldview. The inculcated experiences, behaviours, relationship models and self-image that result from this worldview are explained.

This kind of musical experience research method has a great advantage: the research results arise from naturally occurring experiences of all types of musical manifestation, as opposed to an experimental (artificially controlled) situation. The results acquired provide information about the first powerful impressions a person has, which very often are crucial for developing their overall attitude towards music. Furthermore, information about the significant role played by the environment, the surrounding people and the situation in the existence of music as a phenomenon was obtained. It has been shown that the very first powerful musical impression affects choice of profession and further musical development. It also seems important that adults can describe retrospective experience from their childhood that they would not have been able to express as children.

\section{References}

Batt-Rawden, K., \& DeNora, T. (2005). Music and informal learning in everyday life. Music Education Research, 7 (3), p. 289-304.

Becker, J. (2004). Deep Listeners: Music, Emotion and Trancing. Bloomington: Indiana Press. 
Clarke, E., Dibben, N., \& Pitts, S. (2010). Music and Mind in Everyday Life. Oxford: Oxford University Press.

DeNora, T. (2000). Music in Everyday Life. Cambridge: Cambridge University Press.

DeNora, T., Ruud, E., \& Batt-Rawden, K. (2005). Music listening and empowerment in health promotion a study of the role and significance of music in everyday life of the long-term III. Nordic Journal of Music Therapy, 14 (2), p. 120-136.

Elliott, D. (1995). Music matters: A new philosophy of music education. New York: Oxford University Press

Frith, S. (2002). Music and everyday life. Critical Quarterly, 44 (1), p. 35-48.

Gabrielsson, A., \& Lindström Wik, S. (2003). Strong experiences related to music: A descriptive system. Musicae Scientiae, VII (2), p. 157-217.

Giorgi, A. (1975). An application of phenomenological method in psychology. In A. Giorgi, Fischer, C., \& Murray, E. (Eds.). Duquesne studies in phenomenological Psychology I, p. 82-103. Pittsburgh, PA: Duquesne University Press

Giorgi, A. (1985). Sketch of a psychological phenomenological method. In A. Giorgi (Ed.), Phenomenology and psychological research, p. 8-22. Pittsburgh, PA: Duquesne University Press.

Griten E. (2015). Empathic Listening as a Transferable Skill. Empirical Musicology Review. Vol. 10, No. 1.

Hargreaves, D. J., \& North, A. C. (1999). The functions of music in everyday life: Redefining the social in music psychology. Psychology of Music, 27 (1), p. 71-83.

Herbert, R. (2011). Everyday Music Listening: Absorption, Dissociation and Trancing. Hardcover: 244 pages; Publisher: Routledge.

Juslin, P., \& Sloboda, J. A. (Eds.). (2001). Music and Emotion: Theory and Research. Oxford: Oxford University Press.

Paipare, M. (2003). Klausīšanās un mūzikas klausǐšanās prasmju mijattiecības skolotāju sagatavošanā. In Skolotāju izglìtības problèmas un to risinājumi, 3. d. Liepāja, p. 149-156.

Paipare, M. (2004). Mūzikas uztveres integratīvā darbība. Teorija un prakse skolotāju izglìtībā II Rìga, RPIVA, p. 47-52.

Paipare, M. (2006). Mūzikas klausī̌̌anās kā izziṇas process. In Pedagogiija: teorija un prakse IV Liepāja, p. 240-245.

Paipare, M. (2012). Muzikālais pārdzīvojums psihologiskajā un terapeitiskajā aspektā. In Sabiedrība, integrācija, izglītība. Starptautiskās zinātniskās konferences materiāli 2012. gada 25.-26. maijs, II daļa. - Rēzekne: RA Izdevniecība, p. 154-162.

Peters, D. (2015). Musical empathy, emotional co-constitution, and the "musical other". Empirical Musicology Review, 10 (1), p. 2-15.

Ricoeur, Paul (1971). The Model of the Text: Meaningful Action Considered as a Text. Social Research, 38 (3), p. 529-562.

Ruud, E. (2004). Foreword: Reclaiming Music. In M. Pavlicevic \& G. Ansdell (Eds.), Community Music Therapy, p. 11-14. London: Jessica Kingsley.

Small, C. (1998). Musicking: The Meanings of Performing and Listening. Middletown, Conn.: Wesleyan University Press; Hanover, N. H.: University Press of New England.

Van Manen, Max (1990). Researching Lived Experience. Albany, NY: SUNY Press.

Von Eckartsberg, R. (1998). Existential-Phenomenological Research. In Valle, R. (Ed.) In Phenomenological Enquiry in Psychology. Existential and Transpersonal Dimensions. New York: Springer, p. 21-62. 
Mirdza Paipare. Music Listening as Musicking and Strong Musical Experience

Wallrup, Erik (2015). Being Musically Attuned, Being Musically Attuned: The Act of Listening to Music. Aldershot: Ashgate, 2015 Available: http://sonicstudies.org/ wallrup 2015

Whaley, J., Sloboda, J. A., \& Gabrielsson, A. (2009). Peak experiences in music. In S. Hallam, I. Cross, \& M. Thaut (Eds.), The Oxford handbook of music psychology, p. 452-461. Oxford, UK: Oxford University Press 